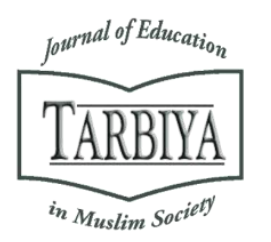

Available online at TARBIYA: Journal of Education in Muslim Society Website:

http://journal.uinjkt.ac.id/index.php/tarbiya

TARBIYA: Journal of Education in Muslim Society, 4(1), 2017, 32-44

\title{
THE INFLUENCE OF PARENTS' PARENTING AND EMOTIONAL QUOTIENT ON STUDENTS' SOCIAL SKILLS
}

\author{
Siti Masyithoh \\ Syarif Hidayatullah State Islamic University of Jakarta, Indonesia \\ E-mail: siti.masyithoh@uinjkt.ac.id
}

Received: 08 ${ }^{\text {th }}$ March 2017; Revised: $15^{\text {th }}$ May 2017; Accepted: $26^{\text {th }}$ June 2017

\begin{abstract}
This research aims at knowing and finding empirical data about the influence of independent variables, i.e., parenting and emotional quotient on students' social skills as a dependent variable. This study employed a quantitative research design in the form of ex-post-facto or causal comparative with the $3 \times 2$ factorial design. The method used to collect the data was surveyed with a questionnaire. The data were analyzed by using twoway analysis of variance. The samples are 172 students of the elementary school in Mustika Jaya Bekasi. The result of this research showed that the social skills gained by the students with democratic parenting on average were highest among others. Further, the students having high emotional quotient showed better social skills compared to those with low emotional quotient. The students raised with democratic parenting both with high and low emotional quotient earned the highest social skills. Students with high emotional quotient nurtured by permissive parenting showed better social skills than those raised by authoritarian parenting. In contrast, students with low emotional quotient raised with authoritarian parenting produced better social skills than those nurtured by permissive parenting. So, there is the influence of parenting and emotional quotient on students' social skills at $6^{\text {th }}$ Grade of elementary schools in Mustika Jaya Bekasi District.
\end{abstract}

Keywords: parents' parenting; emotional quotient; social skills

\section{Abstrak}

Penelitian ini bertujuan untuk mengetahui dan menemukan data empiris tentang pengaruh variabel bebas, yaitu pola asuh dan kecerdasan emosional terhadap ketrampilan sosial siswa sebagai variabel dependen. Penelitian ini menggunakan rancangan penelitian kuantitatif dalam bentuk kompresif faktual atau komparatif kausal dengan 3×2 desain faktorial. Metode yang digunakan untuk mengumpulkan data adalah survei dengan kuesioner. Data dianalisis dengan menggunakan analisis varian dua arah. Sampelnya adalah 172 siswa sekolah dasar di Mustika Jaya Bekasi. Hasil penelitian ini menunjukkan bahwa keterampilan sosial yang diperoleh siswa dengan pola asuh demokratik rata-rata paling tinggi. Selanjutnya, siswa yang memiliki kecerdasan emosional tinggi menunjukkan kemampuan sosial yang lebih baik dibandingkan dengan mereka yang memiliki kecerdasan emosional rendah. Para siswa yang diangkat dengan pola asuh demokratis baik dengan kecerdasan emosional tinggi maupun rendah memperoleh keterampilan sosial tertinggi. Siswa dengan kecerdasan emosional tinggi yang dipelihara dengan pola asuh permisif menunjukkan kemampuan sosial yang lebih baik daripada yang diangkat oleh pola asuh otoriter. Sebaliknya, siswa dengan kecerdasan emosional rendah yang diangkat dengan pola asuh otoriter menghasilkan keterampilan sosial yang lebih baik daripada yang dipelihara oleh pola asuh permisif. Jadi, ada pengaruh parenting dan emotional quotient terhadap keterampilan sosial siswa di kelas 6 SD di Mustika Jaya Kabupaten Bekasi.Kata kunci: orangtua orangtua, kecerdasan emosi, keterampilan sosial.

Kata kunci: orang tua; kecerdasan emosi; keterampilan sosial

How to Cite : Masyithoh, S. (2017). The Influence of Parents' Parenting and Emotional Quotient on Students' Social Skills. TARBIYA: Journal of Education in Muslim Society, 4(1), 32-44 doi:10.15408/tjems.v4i1.5901.

Permalink/DOI: http://dx.doi.org/10.15408/tjems.v4i1.5901 


\section{Introduction}

The main purpose of education is to provide a circumstance and environment in which students able to improve their talents and skills optimally. Therefore, they can achieve their goals and be part of society optimally to achieve the personal needs and society's expectation. Improving talents and skills optimally mean improving all aspects, intellectual, social, emotional, and spiritual. In another word, intellectual is not the only aspect of educational goal, especially when it related with the future in which someones intellectual is not the only factor, but also many other factors, including social aspect.

There are plenty of bullying cases in elementary level, for example; bullying that was committed by an elementary students in Bukit Tinggi, West Sumatra (Munir, 2014), $5^{\text {th }}$ grade students of SDN Bintara II who got problem in his eyes because of bullying committed by his classmate (Republika, 2015), bullying by $6^{\text {th }}$ grade students of Aceh Besar to one of their classmate that lead to her death (Detik, 2015), and many other cases of bullying in Indonesia, either reported or not, that becomes the main concern of education practitioner. All of that conditions show that Indonesian elementary students' social skill is decreasing day by day. This condition is become problematic, especially when social is be one of the most important aspects that leads to someone's success in the future.

The development of the social skill of an individual relates to internal and external factors of the individual himself. Internal factors are factors from the inside of the person, such as genetic, neurotic problems, and personal condition, cognitive, intellectual, emotional, temperament, and personal characteristics. While external factors are factors outside of the person, such as internal communication with families, school, and society environment.

The effect of emotional quotient to students' social ability has been proved by Mestre et al. (2006: 112-117) with their research to teenagers in Spain. In their research, they found that emotional quotient has a positive effect to the social competency for teenager. The way parents treat their children in the home also affects children' social life. Authoritative circumstances in home lead children into a follower. While democratic circumstances create leadership for children (Hurlock, 1980: 173). In the family, children will learn about the right pattern and learn how to be part of the society and taught how to act properly and accepted by society. This statement is strengthened with the research conducted by Vijila et al. (2013: 34-36) that stated in their thesis, teenagers who are raised in democratic circumstances show better social competencies than those who are raised in permissive and authoritative circumstances.

Based on the explanation above, it is necessary to have research that explains better about social ability in elementary school. And, in this research to prove the effect of parenting style and emotional quotient to social skill, and the effect of those two variables to the improvement of students' social skill.

\section{Social Skill}

Social skill is a knowledge of human behavior and intra process, an ability to understand feeling, behavior, others' motivation of utterance and action, ability to communicate clearly and effectively, and ability to have a cooperative and effective relationship (Devins et al., 2004:11)

Social skill gives a view about children' ability to interact, and preferences with other, build and hold a relationship, and avoiding responses which unacceptable socially (A Review 
for the Early Intervention Foundation, 2015: 29). Patrick in Malikeh and Taube (2013: 75) define social skill as a set of skill use to interact and communicate with others. While Libet and Levinson still in Malikeh and Taube (2013: 75) define social skill as. "a complex ability that produces behaviors that will be positively reinforced and not produce behaviors that will be punished by others."

Social skill is a tool that makes people able to communicate, learn to ask, asking for help, fulfill their need properly, interact with others, build and hold good relationship, protecting self, and ability to interact with anybody and everybody they meet in their life (Dowd and Tierney, 2005:1). For that, children are required to master the social skills and ability to adapt to the environments.

Based on all the theories above it can be concluded that social skill is very urgent and vital for human as a social being because social skill is the real way to involve, communicate, and respond to others in a relationship and interaction.

\section{Social Development in Elementary Students}

Elementary school is a prominent and decisive phase in the process of someone social skill development (Johnston and Halocha, 2010: 169). In this phase, individual someone skill is developing. Based on Erikson in Slavin (2006:94), the age from 9 to 12 is the moment of hard working versus inferiority. According to him, the school gives a very big impact on the improvement of children potential in the society, social skill, and having a self-concept. Based on that point, Erikson believes that teachers have responsibility especially to the development of children' active moment.

Hale, Dariotis, and Kuah in Slavin (2006: 79) said that childhood is "independent action, cooperation with the group, and performing in socially acceptable ways with concern." In this age, children start making group. They feel uncomfortable without their friends (Hurlock, 1980: 155). They start to adapt with groups' norm, custom, and moral. Therefore, in the process of socialization, children act to be accepted in their group, playing a role, and behave according to the rule of the group. In their group, their social life has expanded. They do not only learn about team work, but also respect, empathy, and responsible (Yusuf, 2011: 181).

According to Singer in Papalia (2009: 278), the social act is a prosocial act; all of the action and deed to help others, such as teamwork, empathy, sympathy, generosity, and helping each other. Those who prosocial are those who have very good social skill Dryden $\&$ Vos (2000: 350 ) stated that the characteristics of those who have good social skill have many friends, actively involved in the school and neighborhood, know the environment well, actively involved with group activity outside the school, be the mediator among their friends or families, enjoying groups' play, have the good sense sympathy to other, problem solver among their friends, enjoying teaching and advising others, and show good leadership.

Based on theories proposed by experts, it could be concluded that social skill, in this research, is someone's ability to communicate, empathy, make teamwork, responsible effectively, help others, be generous, act according to rule and norm, and be part of social activity.

\section{Parenting Style}

The family has prominent position and role in developing children's personality. A parenting style that develops caring and educating with life value, either religiously or socially, are conducive factors to make children have a good personality and be part of society. 
Children who grow with different families. As explained previously, the family is one of the social contexts in which children live, will affecting their development, including social development. According to Hurlock (1980: 170), the effect of children and parents relationship, clearly seen in aspects of life. Some of the most important value is as follow:

First, children's work and behavior in school are determined by their relationship with their family. A good and sound relationship within the family leads children's success in school, while a not good and sound relationship lead to emotional responses and bad effects to concentrate and study.

Second, the relationship within the family affects social adaptation outside the home. If the relationship is sound and good, the adaptation will be better than those who do not.

Third, role inside the home determines role outside the home, because the role inside the home and the relationship between siblings lead to the way children build a relationship outside the home. Therefore, this condition affects children act to friends.

Fourth, a training method for children in the home affects their role. If the method is authoritative, children learn to be a follower, and mostly be the unsatisfied follower as the reflection of their relationship with parents. While democratic method leads to leadership.

Fifth, children are creative and conformist in the act as those are determined by the training in the home. Democratic training method leads to creativity, while authoritative leads to conformist.

Sixth, the relationship within the family has a prominent role in developing children's personality. Their point of view of themselves is the reflection of values of how they are treated by their family.

Based on the previous explanation, training method or commonly known as parenting style has prominent effect to children social development. Approach pattern and interaction between parents and their children for an educational process within the family is commonly called parenting style. Gunarsa (1983: 24) stated parenting style is a common way used by parents to teach their children in a family which commonly based on dominant factors of the parents. In line with Gunarsa, Santoso (2004: 77) defined parenting style as the approaches of an adult to children to guide, affect their behavior, and teach them to be mature and independent. While Grant and Ray (2013: 60) define parenting style as "is the general pattern of these child rearing practices or a set of parenting behaviors."

Based on the previous explanation, then it could be concluded parenting style is an interaction pattern between parents and children that related with the way to communicate, appreciate, care, discipline and behave to children.

\section{Types of Parenting Style}

Based on the Baumrind's research finding as quoted by Grant and Ray (2016: 63) found that differences in parenting style will result in different profile of behavior for children. It is also found that among all parenting style, democratic parenting style results positive profile. These are the three types of parenting style proposed by Yusuf (2011: 51-52) based on Baumrind's research in table 1. 
TABLE 1. Parenting Style to Children's Behavior

\begin{tabular}{|c|c|c|}
\hline PARENTING STYLE & PARENTS' BEHAVIOR & CHILDREN'S BEHAVIOR \\
\hline 1. Authoritarian & $\begin{array}{l}\text { 1. The acceptance is the low and high rate } \\
\text { of control. } \\
\text { 2. Physical punishments are common } \\
\text { 3. Giving order without compromises } \\
\text { 4. Rigid } \\
\text { 5. Tend to be emotional and refuse }\end{array}$ & $\begin{array}{l}\text { 1. Easily offended } \\
\text { 2. Fainthearted } \\
\text { 3. Depressed, unhappy } \\
\text { 4. Easily influenced by other } \\
\text { 5. Easily stressed } \\
\text { 6. Has no clear vision of future } \\
\text { 7. Hard to socialize with others } \\
\end{array}$ \\
\hline 2. Permissive & $\begin{array}{l}\text { 1. High acceptance, but low rate of } \\
\text { controlling } \\
\text { 2. Give freedom to children } \\
\text { 3. Tend to spoil children }\end{array}$ & $\begin{array}{l}\text { 1. Impulsive and aggressive } \\
\text { 2. Rebellious } \\
\text { 3. Low self-confidence and self-control } \\
\text { 4. Dominating } \\
\text { 5. Has no clear vision of the future } \\
\text { 6. Little achievement }\end{array}$ \\
\hline Authoritative & $\begin{array}{l}\text { 1. High acceptance and high rate of } \\
\text { controlling } \\
\text { 2. Responsive to children's needs } \\
\text { 3. Motivating children to express ideas or } \\
\text { questioning } \\
\text { 4. Explaining good and bad deed }\end{array}$ & $\begin{array}{l}\text { 1. Friendly } \\
\text { 2. Good self-confidence } \\
\text { 3. Good self-controlling } \\
\text { 4. Polite } \\
\text { 5. Able to work in team } \\
\text { 6. High curiosity } \\
\text { 7. Clear vision of life } \\
\text { 8. Have good in achievement in life }\end{array}$ \\
\hline
\end{tabular}

\section{Emotional Quotient}

The term emotional quotient based on Shapiro in Aunurrahman (2012: 85), first time proposed in 1990 by psychologists Peter Salovey from Harvard University and John Meyer from University of New Hampshire. They defined emotional quotient as a part of a collection of social quotient that involves ability to understand feeling and emotion, either to themselves or others, be able to decide wisely, and used the information as guidance of mind and act.

Goleman (1995: 34) stated that emotional intelligence: "abilities such as being able to motivate oneself and persist in the face of frustrations; to control impulse and delay gratification; to regulate one's moods and keep distress from swamping the ability to think; to empathize and to hope."

In contrast to Goleman, Salovey and Meyer outlines areas of emotional intelligence as follows:
"Emotional intelligence involves the ability to perceive accurately, appraise, and express emotion; the ability to understand emotion and emotional knowledge; and ability to regulate emotions to promote emotional and intellectual growth.” (Salovey and Sulyster, 2004: 197-215).

Though Salovey and Meyer stated emotional quotient in more detail and specific way, but Goleman's has more meaning. As Goleman put to hope as the main aspects of emotional quotient. Someone who has good emotional quotient will be able to see clearly and find the solutions with putting their hope to God.

The same definition also stated by Patton (2000: 1). Based on Patton, emotional quotient is the source of power of intellectuality that be the foundation of emotional building with some abilities, including: controlling satisfactory and impulses, but still optimistic when face problems or uncertainty, handling strong emotions effectively, able to motivate and keep the discipline in order to achieve goals, managing personal's weaknesses, showing empathy to 
others, and building self-consciousness and understanding.

Hughes and Thompson (2009: 118) stated that emotional quotient is, "A person's innate ability to perceive and manage his/her own emotions in a manner that results in successful interactions with the environment and if others are present, to also perceive and manage their emotions in a manner that results in successful interpersonal interactions."

Based on the previous explanations it can be concluded that emotional quotient is an ability to recognize self-emotion, manage it, be able to motivate own self, and others emotion. That four dimension can be seen from several indicators, such as: expressing and understanding self-emotion and others, managing it, motivating own self, independence, ability to adapt, be loved by others, diligent, stand of frustration, and problem-solving

\section{Method}

This research is a quantitative research used ex post facto or causal comparative with analysis of variance $3 \times 2$ technique. The research was conducted in class VI Mustika Jaya Bekasi elementary school in the middle of academic year 2015/2016. The population of the research is all of the student's grade VI Mustika Jaya district of Bekasi with total 36 schools; 22 state schools and 14 private schools. The sample of the research is 254 elementary students from 5 school-groups in 4 sub-districts. Then all 254 samples are divided into three groups of emotional quotient. 1/3 first and 1/3 second are used as the samples. Therefore, the total sample using analysis of variance is 172 students. Sampling techniques used is multistage cluster random sampling.

Data are analyzing technique that is used including descriptive analysis and inferential analysis. Data analysis with inferential analysis used Two Way Analysis of Variance or abbreviate as ANOVA. All measurement is conducted with significance value $\alpha 0,05$. There are three data collected; those are social skill, parenting style, and children's emotional quotient. The instrument used to collect the data is validated questionnaire.

\section{Findings and Discussion}

\section{Finding}

After counted with Ms. Office Excel, the summary for statistical descriptive is as follow:

Table 2. Data Descriptive Summary of Social Skill

\begin{tabular}{lllll}
\hline Parenting & Emotional & Mean & Std. & $\mathrm{N}$ \\
Style & Quotient & & Deviation & \\
Democratic & High & 85.84 & 5.409 & 58 \\
& Low & 74.77 & 3.980 & 30 \\
& Total & 82.07 & 7.235 & 88 \\
\hline
\end{tabular}

Then the calculation is conducted with $M s$. Office Excel and SPSS 16.0 for Window. The result of analysis of variance is as follow:

Table 5. ANOVA

\begin{tabular}{|c|c|c|c|c|c|c|c|}
\hline \multirow{2}{*}{$\begin{array}{l}\text { Source } \\
\text { Variant } \\
\text { s }\end{array}$} & \multirow[t]{2}{*}{ JK } & \multirow{2}{*}{$\begin{array}{l}\mathrm{D} \\
\mathrm{b}\end{array}$} & \multirow[t]{2}{*}{ RJK } & \multirow[t]{2}{*}{ Sig } & \multirow[t]{2}{*}{$\mathrm{F}_{\text {obs }}$} & \multicolumn{2}{|c|}{$\mathrm{F}_{\text {tablc }}$} \\
\hline & & & & & & $\begin{array}{l}\boldsymbol{\alpha} \\
= \\
0,0 \\
5\end{array}$ & $\begin{array}{l}\alpha= \\
0,0 \\
1\end{array}$ \\
\hline Inter A & $\begin{array}{l}314,89 \\
9\end{array}$ & 2 & $\begin{array}{l}157,4 \\
50\end{array}$ & $\begin{array}{l}0,0 \\
08\end{array}$ & 4,930 & $\begin{array}{l}3,0 \\
6\end{array}$ & $\begin{array}{l}4,7 \\
5\end{array}$ \\
\hline Inter B & $\begin{array}{l}3601,2 \\
11\end{array}$ & 1 & $\begin{array}{l}3601, \\
211\end{array}$ & $\begin{array}{l}0,0 \\
00\end{array}$ & $\begin{array}{l}112,7 \\
66\end{array}$ & $\begin{array}{l}3,9 \\
1\end{array}$ & $\begin{array}{l}6,8 \\
1\end{array}$ \\
\hline $\begin{array}{l}\text { Interact } \\
\text { ion A x } \\
\text { B }\end{array}$ & $\begin{array}{l}116,42 \\
4\end{array}$ & 2 & $\begin{array}{l}58,21 \\
2\end{array}$ & $\begin{array}{l}0,1 \\
65\end{array}$ & 1,823 & $\begin{array}{l}3,0 \\
6\end{array}$ & $\begin{array}{l}4,7 \\
5\end{array}$ \\
\hline Within & $\begin{array}{l}5301,2 \\
55\end{array}$ & $\begin{array}{l}16 \\
6\end{array}$ & $\begin{array}{l}31,93 \\
5\end{array}$ & & & & \\
\hline Total & $\begin{array}{l}11372, \\
465\end{array}$ & $\begin{array}{l}17 \\
1\end{array}$ & & & & & \\
\hline
\end{tabular}

Summary:

1. $\mathrm{H}_{0}$ is rejected if $\mathrm{F}_{(\mathrm{A})}>\mathrm{F}_{\text {table }}$. or $P$-value $<$ 0,05 . Therefore, it can be said there are differences between students' social skill average score from democratic, authoritative, and permissive parenting style group. 
2. $\mathrm{H}_{0}$ is rejected if $\mathrm{F}_{(\mathrm{B})}>\mathrm{F}_{\text {table }}$ or P-value $<$ 0,05 . Therefore, it can be said there are differences between students with high emotional quotient and low emotional quotient.

3. $\mathrm{H}_{0}$ is accepted if $\mathrm{F}_{(\mathrm{AB})}<\mathrm{F}_{\text {tabe }}$ l. or $P$-value $>0,05$. Therefore, it can be concluded there is no interaction effect between parenting style factor and emotional quotient factor with students' social skill. In another word, the effect of parenting style to students' social skill is not determined by students' emotional quotient. Because there is no interaction, the hypothesis between cells should not be tested.

\section{Discussion}

The Contrast between Students' Social Skill and Democratic Parenting Style and Authoritative Parenting Style.

Dunnet t-test's calculation found that observe $=4.7333$ is bigger than $t_{\text {table }}=1.645$. Therefore, if $t_{\text {observe }}>t_{\text {table }} \mathrm{H}_{0}$ is rejected and $\mathrm{H}_{1}$ is accepted In another word, the social skill of the students' with democratic parenting style is bigger than students' with authoritative parenting style. Those conditions can be seen from the average of democratic parenting style 82.07 which is bigger than authoritative parenting style 76.61 . The average difference is 5.462 . The difference is big as $P$-value bigger than 0,00 and smaller than 0,01. Empirical data finding proved the theory that explained about students' with democratic parenting style psychologically competent and socially better compare those with others parenting style (Krause and Dailey, 2009, 342). While students that are raised with authoritative parenting style or frequently punished will most likely have low social competencies. They tend to be worried about the social situation, has no initiative to be active and low communication skill, students' to be a coward and follower (Santrock, 2007: 74). This opinion is strengthened with empirical data found by the researcher, that students' with democratic parenting style has better social competencies compare to those raised with authoritative parenting style. Democratic parenting style leads to cheerful, easily to adapt, be loved, have social initiatives, and able to finish social problems students.

Therefore, based on the research finding, parents, teachers, and neighborhood that involved in students' parenting style to be more democratic than authoritative.Parents should be more accommodative to their children, give logical consequences to the mistakes, and positive enhancement to children's achievement, and not give limitless punishment, not accommodative with children, not responsive, over protective, emotional, and ignoring children's achievement. By that, it is hoped that there will come students' with good social competencies, cheerful, and dare to take risk, not those with personal anxiety, afraid of risk, coward, and afraid to express idea, which lead to be easily influenced by bad environment,, and tend to be the victim of violence among them.

The Contrast between Students' Social Skill between Those with Democratic Parenting Style and Permissive Parenting Style.

Dunnet t-test's calculation found that $\mathrm{t}_{\text {observe }}$ $=6.1437$ is bigger than $t_{\text {table }}=1.645$. Therefore, if $t_{\text {observe }}>t_{\text {table }} H_{0}$ is rejected and $\mathrm{H}_{1}$ is accepted. In another word, the social skill of the students' with democratic parenting style is bigger than students' with permissive parenting style. Those conditions can be seen from the average of democratic parenting style 82.07 which is bigger than permissive parenting style 75.96. The average difference is 6.107 . The difference is big as $P$-value bigger than 0,00 and smaller than 0,01. Empirical data finding proved the theory 
that explained about students' with democratic parenting style psychologically competent and socially better compare those with others parenting style (Krause and Dailey, 2009, 342). Compared to those with permissive parenting style which tend to be unable in controlling behavior, selfish, and socially in trouble (Santrock, 2007: 74). Permissive parents tend to give full freedom, without guidance about the social rule, and low control. Parents tend to fulfill children's wants and tend to give an excessive respond.

Therefore, based on the research finding, parents, teachers, and neighborhood that involved in students' parenting style to be more democratic than permissive. Parents should be more accommodative to their children, give logical consequences to the mistakes, and positive enhancement to children's achievement, and not give limitless punishment, not accommodative with children, not responsive, over protective, emotional, and ignoring children's achievement. By that, it is hoped that there will come students' with good social competencies, cheerful, and dare to take risk, not those with personal anxiety, afraid of risk, coward, and afraid to express idea, which lead to be easily influenced by bad environment,, and tend to be the victim of violence among them.

The Contrast between Students' Social Skill between Those with Authoritative Parenting Style and Permissive Parenting Style.

Based on the statistical calculation using Dunnet $\mathrm{t}$-test with Ms. Excel found that $\mathrm{t}_{\text {observe }}=$ 0,5149 smaller than $t_{\text {table }}=1,645$. If $t_{o}<t_{t}$, then $\mathrm{H}_{1}$ is rejected and $\mathrm{H}_{0}$ is accepted. In another word, there are no significance differences of social skill between students who are raised with authoritative parenting style and permissive parenting style. It could be seen from the mean of authoritative parenting style score 76,61 and the mean of permissive parenting style score
75,96, with coefficient between those two 0,645. The difference is not significance, because $P$ value is 0,721 bigger than 0,05 . Therefore, based on the result it can be concluded that social skill of the grade $6^{\text {th }}$ elementary schools students in Mustika Jaya District of Bekasi who are raised with authoritative parenting style and permissive parenting style have no differences. The result is probably caused by the authoritative parenting style that frequently uses punishment leads to students that are not competent socially. They tend to be anxious with a social situation, has no initiative in their activity, low communication skill, be a coward, and not able to express their thought (Santrock, 2007: 74). In another word, based on Santrock, students with authoritative parenting style have low social competences. In another hand those who are raised with permissive parenting style commonly unable to control their act, selfish, and socially problematic. Both of that parenting style is socially problematic. Children with authoritative parenting style tend to be the object of violence, and those with permissive parenting style are the subject

Therefore based on the research, it is hoped that parents, teachers, and environment do not use authoritative or permissive parenting style that ten to lead children not competence socially. Both authoritative and permissive has bad effect to children's personality. Permissive parenting style tends to create selfishly, vandal, and not responsible, while authoritative, oppositely, tend to create children to be a coward, unable to express ideas and terrible communication skill.

There is an Interactional Effect between Parenting Style and Students' Social Skill.

Based on the analysis of the data to the interactional effect of those two factors; parenting style and social skill, found that $\mathrm{F}_{(\mathrm{AB})}<$ $\mathrm{F}_{\text {table }}$ or $P$-value $>0,05$, which means there is no interactional effect between those two factors. It 
means that parenting style affects students' social skill, but not determined with students' emotional quotient. Oppositely, students' emotional quotient could affect students' social skill, but not determined by parenting style. It means, students with high emotional quotient level, raised with any parenting style, is still going to have high social skill compare to those with low emotional quotient. It can be seen from the effect of students' emotional quotient to social skill 39.4\%, compared to the effect of parenting style on social skill $4.4 \%$. The big effect of this condition is caused by the emotional quotient as an innate potential, manage, and control by amygdala, a part of the brain (Le Doux, 1994: 50-57). This high innate potential will create output in the form of social skill if raised with democratic parenting style.

Therefore, based on the research, there is no interactional effect between parenting style factor and emotional quotient to the social skill of grade VI elementary schools students in Mustika Jaya district of Bekasi. In another word, emotional factor as an innate factor has a bigger effect than parenting style as an external factor of the students. Even though applying proper parenting style is prominent, but based on the research the development of emotional quotient is more important.

The empirical fact of the research could motivate parents, teachers, and environment of the students to be more concern with the development of emotional quotient, as innate factor, by giving a continuous stimulus. It is hoped that students' emotional quotient can develop optimally and maximally. Therefore, students can make a positive social act for themselves and environment, such as; managing satisfactory and impulses, optimist during problem and uncertainty, distributing strong emotion effectively, motivating and keeping discipline to achieve goals, managing selfweaknesses, showing empathy to others, and having self-understanding. By that, any destructive behavior can be minimalized since childhood. The result of this research contrasts with Goleman's idea in Jensen (2006: 31) that $80 \%$ of behavior is affected by environment factor.

Though there is no interactional effect between parenting style and emotional quotient, based on the profile of the data, there is an intersection between authoritative and permissive parenting style to high-level of the emotional quotient with authoritative and permissive parenting style to low-level of emotional quotient. Following the t-test is the result that in high-level emotional quotient, students who are raised with permissive parenting style has a better social skill that those with authoritative parenting style. While in lowlevel emotional quotient authoritative parenting style results in better social skill than permissive parenting style.

Contrast between Social Skill in Authoritative and Permissive Parenting Style to High-level Emotional Quotient

Based on Dunnet t-test result found that $\mathrm{t}_{\text {observe }}=-2.8907$ smaller than $\mathrm{t}_{\text {table }}=-1.645$. If $\mathrm{t}_{\text {observe }}<\mathrm{t}_{\text {table, }}$, then $\mathrm{H}_{0}$ is rejected and $\mathrm{H}_{1}$ is accepted. In another word, the social skill of the students from authoritative parenting style is lower than permissive parenting style. It can be seen from the average of authoritative parenting style in high-level emotional quotient 80.86 which is smaller than permissive parenting style in high-level emotional quotient 83.83 with the average coefficient difference -5.812 .

Empirical data of the research found could be explained. Theoretically, students with highlevel emotional quotient tend to have a better social relationship, understanding each other and few social conflict (Yun Dai and Sternberg, 2004: 182). It is because students with high-level of emotional quotient more able to recognize 
own and other emotion, managing own emotion, having a relationship with other and more independent (Hughes and Thompson, 2009: 118). This type of students if raise with a permissive parenting style that tends to give freedom, spoil, and almost no consequences given, will have better social skill than those with an authoritative parenting style that is more punished and dictate. The reasons are, as explained previously about high-level of emotional quotient, has better intellectuality that is the foundation of emotion, including plenty of skills and ability to manage emotion.

Based on neuroscience, a student with highlevel of intellectuality able to manage amygdala optimally and as a result few condition of the emotional problem. Therefore, students with high-level emotional quotient will have better social skill when raising with permissive than authoritative parenting style.

Based on the findings, the high-level emotional quotient of grade VI students of elementary schools in Mustika Jaya district, Bekasi are raised with authoritative parenting style have lower level social skill than those raised with who are raised with permissive parenting style. It means that it will be better for a student with high-level emotional quotient to be raised with permissive parenting style than authoritative parenting style. It because authoritative parenting style which is rigid and uses punishment will not give more flexibility for the students to improve their potential emotion. Students will be more depress and will result in their social skill not improve well. High-level emotional quotient students that are raised with permissive parenting skill will have the better social skill, because permissive parenting style tends to let the students act freely and almost without control and pressure, give more freedom for the students to develop its potential emotion.
Contrast of Social Skill between Authoritative Parenting Style and Permissive Parenting Style to Low-level Emotional Quotient

After the Dunnet t-test with Microsoft Excel found $t_{\text {observe }}=2.1678$ bigger than $t_{\text {table }}=$ 1.645. If $t_{\text {observe }}>t_{\text {table }}, H_{0}$ is rejected, and $H_{1}$ accepted. It means social skill for low-level emotional quotient that is raised with authoritative parenting style is higher than those from permissive parenting style. It can be seen from the average score of the low-level emotional quotient of students who are raised with authoritative parenting style 73.47 bigger that permissive parenting style 71.67 with coefficient 3.528 .

Empirical data that are found could be theoretically explained. Students with low emotional quotient level tend to do not have a social relationship, no understanding with each other and more social conflict (Yun Dai and Sternberg, 2004: 182). Because students with low-level emotional quotient tend to be unable to understand own and others emotion, unable to control emotion, unable to have a relationship with other, and not independent (Hughes and Thompson, 2009: 118).

To the low-level emotional quotient students, the robbery of information in amygdala is common. It means, most of the time information from thalamus do not go to neocortex first and lead to more irrational and emotional response. It happens because when amygdala works, neocortex is in the process of formulating order (LeDoux, 1995: 209- 235). Students with low-level of emotional quotient, according to Santrock (2007: 74), need more control and evaluation from their parents. Therefore, low-level emotional quotient level will have better social skill when raising with authoritative parenting style rather than permissive. As explained that permissive parenting style tend to ignore control, do not 
care about students' life and activity, has less or no information about their friends, and tend to ignore academic achievement. Permissive parenting style if applied to low-level emotional quotient students will lead to not responsible, selfish, and ignorance personality.

Based on the data, found that students with low-level emotional quotient in grade VI elementary schools in Mustika Jaya, Bekasi have better social skill when raised with authoritative parenting style than permissive parenting style. It proves the theory that students with low-level emotional quotient will be better if raise with authoritative parenting style than permissive parenting style. Students with low-level emotional quotient commonly have information robbery in their amygdala. Without strict control, this kind of thing will lead to negative act, no responsibility, and tend to be destructive. Therefore, this kind of students needs strict control from its circumstances, especially parents and teachers.

\section{Conclusions}

The development of social skill is determined by innate factors or the people themselves and stimulus from the surrounding. This research shows that innate factors are more determinate than the surrounding in developing social skill.

Students with democratic parenting style, either in low-level or high-level emotional quotient, have a better average score in social skill than those raised with authoritative or permissive parenting style. Students with highlevel emotional quotient have better social skill if raised with permissive parenting style than authoritative. Oppositely, those with low-level emotional quotient will have better social skill if raised with authoritative parenting style than permissive. The contribution factor of the emotional quotient in affecting social skill is
$39.4 \%$, and it is bigger than parenting style that only contributes $4.4 \%$.

Based on the research conducted, there are some implications, such as for parents to be more caring with students' emotional quotient. As this variable of emotional quotient has a bigger effect on students than parenting style. Students with high-level emotional quotient have better social skill than those with lowemotional quotient despite the parenting style.

In term of parenting style, democratic parenting style is the best among the three parenting style. Therefore, parents, teachers, and environment that involve must be a focus on applying democratic parenting style rather than authoritative and permissive parenting style. It is hoped that there will be students with better social competencies, cheerful and responsible and not the type of students that unable to make a decision, coward, and unable to express an idea. The last type of the students tend to be influenced by bad environment and circumstances and tend to be victims of violence among them. Besides all of the things mentioned previously, the acceptance of the students, control of the students by giving logical sanction or punishment for any negative act or disobey of the rule, and give positive appreciation for achievement, it is hoped by that students will avoid destructive and harmful to others.

As the permissive and authoritative parenting style in emotional quotient has interaction lead parents, teachers, and environment to do more effort to choose parenting style based on students' emotional quotient. Students with high-level emotional should be raised with permissive parenting style as this parenting style gives more space and chance for students to improve their potential emotion. Those are raised with permissive parenting style tend to have more courage in taking social initiative as they tend to have less 
pressure psychologically. By this condition, those with high-level emotional quotient able to produce positive social act.

On the other hand, students with low-level emotional quotient will be better if raised with authoritative parenting style compared with permissive parenting style. Students with lowlevel emotional quotient frequently have information problem in amygdala. If students with low-level emotional quotient will be let without control, they will act negatively, not responsible, and tend to be destructive. Therefore, this kind of students needs strict control and evaluation from the environment, especially teachers and parents.

For the suggestion, the researcher expects teachers and parents to be more involve and responsible to students' education. They have to do the best thing to improve students' emotional quotient by giving precise emotional training, stimulus, and proper guidance. Parents and teachers to learn more to choose proper parenting style to apply interaction and study. As the nature of education is conducting learning technique and providing proper learning places in order to improve all potential of the students optimally, including emotional quotient and social skill. For that, an integrated formal curriculum of improving emotional quotient and social is necessary.

\section{References}

A Review for The Early Intervention Foundation, Social and Emotional Skills in Childhood and Their Long Term Effects on Adult Life, $11^{\text {th }}$ march 2015.

Aunurrahman, Belajar dan Pembelajaran, Bandung: Alfabeta, 2012.

Devins, David, Johnson, Steve and Sutherland, John, Different Skills and Their Different Effect on Personal Development, Journal of European Industrial Training Volume 28 number 1, 2004.

Dowd, Tom and Tierney, Jeff, Teaching Social Skills to Youth, $2^{\text {nd }}$ Edition Boys Town Press: 2005.

Dryden \& Vos, Revolusi Cara Belajar (The Learning Revolution): Belajar Akan Efektif Kalau Anda Dalam Keadaan 'Fun" Bagian II: Sekolah Masa Depan, Bandung: Mizan Media Utama: 2000.

Goleman, Daniel, Emotional Intelligence, New York: Bantain Books, 1995.

Grant, Kathy B. and Ray Julie A., Home, School, and Community Collaboration, $2^{\text {nd }}$ Edition,London: SAGE Publications, 2013.

Gunarsa, Singgih D., Psikologi Perkembangan Murid dan Remaja, Jakarta: BPK Gunung Mulya, 1983.

Hargie, Owen, The Handbook of Communication Skills, third Edition, New York: Routledge, 2006.

http://news.detik.com/berita/3029583/, diakses Senin, 28 Sep 2015.

http://www.republika.co.id/berita/nasional/jabo detabek-nasional, diakses Ahad, 25 Oktober 2015.

Hughes, Marcia, and Thompson, Henry L., Emotional and Social Intelligence, San Fransisco: Preiffer, 2009.

Hurlock, Elizabeth B., Psikologi Perkembangan, Terjemahan Istiwidayanti, Jakarta: Erlangga, 1980.

Jensen, Eric Enriching The Brain: how to maximize every learner's potential, San Fransisco: Jossey Bass, 2006.

Johnston, Jane and Halocha, John, Early Childhood and Primary Education, England: Mc GrawHill, 2010. 
Krause, Pacey H. and Dailey, Tahlia M., Handbook of Parenting: Styles, Stresses, and Strategies, New York: Nova Science Publishers, 2009.

LeDoux, Joseph E., "Emotion:Clues from the Brain”, Annual Review of Psychology, 46, 1995.

Malikeh B. and Taebe N., Social Skills: A Factor to Employees' Success, International Journal of Academic Research in Business and Social Sciences, March 2013, Vol. 3, No. 3.

Munir, Badrul, Anarkis Murid SD, Harian Republika, Sabtu 18 Oktober 2014.

Mestre, et.al., Emotional intelligence and social and academic adaptation to school, Psicothema 2006. Vol. 18.

Papalia, Diane E., Sally Wendkos Olds dan Ruth Duskin Fieldman, Human Development, Perkembangan Manusia. Terjemahan: Brian Marswendy, Jakarta: Salemba Humanika, 2009.

Patton, Patricia, EQ (Emotional Intelligence): Development From Success to Significance, terjemahan Hermes, Mitra Media, 2000.
Salovey, Peter \& Sulyster, D.J., Psychologycal Inquiry, Vol. 15 No.3, 2004.

Santoso, Soegeng, Pendidikan Murid Usia Dini, Jakarta: Citra Pendidikan, 2004.

Santrock, John W., Child Development, Jilid 1 Edisi ke-11, Terjemahan Mila Rahmawati (Jakarta: Erlangga, 2007.

Slavin, Robert E., Educational Psychology: Theory and Practice, $8^{\text {th }}$-ed Boston: Pearson, 2006.

Vijila dkk, Relationship between Parenting Styles and Adolescent Social Competence, IOSR Journal Of Humanities And Social Science (IOSR-JHSS) Volume 17, Issue 3 (Nov. - Dec. 2013).

Yun Dai, David and Sternberg, Robert J., Motivation, Emotion, and Cognition, London: LEA, 2004.

Yusuf, Syamsu, Psikologi Perkembangan Murid dan Remaja, Bandung: Rosdakarya, 2011. 